\title{
NEWWAVE IN ENGLISH LANGUAGE TEACHING
}

\author{
CErgashev K., ORCID: 0000-0003-0884-9263, Uzbekistan State World Languages University, \\ Tashkent,Uzbekistan,ergashev_70@list.ru
}

\section{ИННОВАЦИИ В ОБУЧЕНИИ АНГЛИЙСКОМУ ЯЗЫКУ}

\author{
(CЭргашев К. T., ORCID: 0000-0003-0884-9263, Узбекский государственный университет \\ мировых языков, г. Ташкент, Узбекистан, ergashev_70@list.ru
}

Abstract. In recent years, Information and Communication Technologies (ICT) have been gaining ground in the educational field. Their use in the class of English as a foreign language presents great advantages, not only in terms of linguistic learning - as numerous studies have clearly demonstrated - but also as regards personal skills - since students experience the learning of English from new and novel perspectives. This article offers an analysis of some of the most innovative methodologies nowadays making use of ICTs for the teaching of English.

Аннотащия. В последние годы информационные и коммуникационные технологии (ИКТ) получают все большее распространение в сфере образования. Их использование при обучении английскому языку как иностранному дает большие преимущества не только с точки зрения лингвистического обучения, что было наглядно продемонстрировано многочисленными исследованиями, но и с точки зрения личных навыков, поскольку студенты изучают английский язык по новым технологиям и для новых перспектив. Эта статья предлагает анализ некоторых из самых инновационных методик, в настоящее время использующих ИКТ для преподавания английского языка.

Keywords: Information and Communication Technologies, English language, innovative methodologies, language learning, media education, Independent learning.

Ключевые слова: информационно-коммуникационные технологии, английский язык, инновационные методологии, изучение языка, медиаобразование, самостоятельное обучение.

The practicality of the English language opens innumerable prospects in the social and financial world. Regrettably, the way the English language is taught leaves barely any ground for learners to properly incorporate this language in their daily communication. Changing technologies challenge language teachers who struggle to prepare students with the formats and the strategies they need to be effective in academic, business, and social settings. These challenges start with questions about why we have particular norms around communication. These norms form a culture of communication [1].

Economic and technological developments are increasingly having more and more impact on our social lives. Over the last few years the media, and especially information technology, have developed incredibly fast and have become extremely complex. The daily routine of our students is influenced by media technologies to an extent which we could not have predicted several years ago. In addition to $\mathrm{TV}$, radio, magazines and newspapers, in recent years the computer, the Internet with its chat rooms, mobile phones, etc. have all become an integral part of students' lives [2]. 
The digital age has changed the conditions of life, formation and education. Everything changes around, and accordingly, the attitude towards learning must change. The content of education in a modern comprehensive school remains unilateral; state standards based on an objective approach are morally outdated. Many modern teachers point to the lack of a competent approach, focused on the individuality of the student.

Today, knowledge of English opens a window into a large global world with its wide flow of information and innovations. Nowadays the computer is an effective assistant and integral part of everyone, which allows improving the quality of training and the effectiveness of control. Currently, the use of computers in the educational process is very important [3].

Nowadays the types of technologies available for use in language learning teaching has become various and the methods that they are being used in English teaching all over the world. Since computers began to be presented in language teaching people have rightly interested whether the investment we are making in these technologies gives us value for money. As digital technologies have taken hold in society in general, this particular question is not asked quite so often, but it is still important to make sure that the technologies that we have been used in proper way. People are always worldly-wise to try to make an argument for technology having an effect on the development of pedagogy and in many ways we can see that the use of technology has permitted teachers to re-consider what they are doing [4].

Technology plays a massive part in day to day life for so many of us, it makes sense that it is incorporated into learning [5]. Technology fascinates us and engages us. Encouraging students to take part is arguably the most important part of any lesson plan, incorporating technology especially creatively - could be the element that transforms a dull lesson into a captivating one.

As so much of learning comes from practice outside of the classroom, motivating students with innovative ideas is also important. If a student is interested in what is being taught, they are far more likely to seek more information on their own.

For those students who are less familiar with the technology used in the classroom, using it in lessons provides much-needed practice. Technology isn't set to take a back seat in learning, nor in life in general, and so students value the opportunity to familiarize themselves with using different devices in different ways, not just in developing language skills.

Media education aims to make students media competent, which not only involves knowing how to use a computer and all its related technologies but also requires analyzing and questioning the information provided. So, what seems to be required is not only education for our students on how to use the media but also education about the media and its strategies, which might be manipulative as well as informative. Media education, as already integrated into some curricula, must be a crucial element of today's teaching programmers. This task cannot only be tackled in conventional computer or information technology lessons but should be integrated into all subjects [6].

Obviously, technology is not to be used in place of effective teaching, but interactive tasks, text-to-speech conversion and online tutorials allow students to translate on-the-go. Independent learning, with access to relevant teaching material for support, means more practice and therefore more confidence to push perceived limitations - students are given the courage to try books beyond their current reading level, for example [7].

For our students, practicing English outside of a lesson offers exposure to English culture, and so context around what they are learning. Opportunities to practice English in a real-life setting are far more readily available. This can be from news sites, through social media, or visit online forums, all of which provide a variety in language use that is difficult to replicate in the classroom. 
The success of the usage of information and communication technology is not dependent on the availability or absence of one individual factor but is determined through a dynamic process involving a complex of interrelated reasons. It is suggested that up to date professional development have to be provided for educators to model the new pedagogies and instruments for learning with the purpose of developing the teaching-learning process [8].

Today, new methods of using Internet resources are opposed to traditional teaching foreign languages. To teach communication in a foreign language, you need to create real life situations that will stimulate the study of the material and develop adequate behavior. Now everyone understands that the Internet has tremendous information capabilities and no less impressive services. Whichever way we relate to the Internet, we have to recognize the fact that the worldwide network has become an integral part of modern reality. Many students have long appreciated all the advantages of the Internet and use its services actively in their educational process, while for teachers the space of this world web remains mostly unknown, unfamiliar and to some extent frightening. What kind of help the Internet can provide depends on how we use it for solving didactic tasks [9].

These days every modern teacher uses widely the resources of the global Internet. Preparing messages, students filter a lot of information, if they need to listen to music, and most often view photos. Such tasks for students can use the preparatory stage for the lesson, for example, in combination with the project method, allowing students to apply practically for their knowledge and skills [10]. This is one of the forms of research organization and cognitive activity, in which group activity is successfully realized that allows increasing the motivation for learning a foreign language. In the center of such a work process stands the student himself, with the opportunity to freely express his opinion and practical usage of foreign speech.

Technology allows the generation of knowledge and processes to improve systems that tackle problems and develop human skills. In other words, technology can change how people analyze, access, gather present, simulate and transmit information. The impact of technology is one of the most critical problems in education [11].

The use of information and communication technology provides a fruitful learning environment and it transforms the learning and teaching process in which students deal with knowledge in an active, self-directed and proper way. Information and communication technology is not just regarded as an instrument, which can be used as a replacement for existing teaching ways. Information and communication technology is seen as an important tool to support new methods of teaching and learning. It should be used to develop student's skills for cooperation, communication, problem-solving and lifelong learning [12-13].

In fact, concerning the development of technology, we believe that in future, the use of multimedia English teaching will be further developed. The process of English learning will be more student-centered but less time-consuming. Therefore, it promises that the teaching quality will be improved and students' applied English skill scan is effectively cultivated, meaning that students' communicative competence will be further developed [14].

In conclusion, we believe that this process can fully improve students' ideation and practical language skills, which is helpful and useful to ensure and fulfil an effective result of teaching and learning.

\section{References:}

1. Berge, Z. L. (2009). The role of the online instructor/facilitator. http://www. emoderators.com/moderators/teach_online.html.

2. Grabe and Grabe. Integrating technology for meaningful learning. Houghton Mifflin, 2014. 
3. Holec, H. (2015). Autonomy in foreign language learning. Oxford: Oxford University Press.

4. Mirgiyazova, M. M. (2017). Innovative technologies in teaching English. Young scientist, (25). 301-302.

5. Ghasemi, B., \& Hashemi, M. (2011). ICT: Newwave in English language learning/teaching. Procedia-social and behavioral sciences, 15, 3098-3102. https://doi.org/10.1016/j.sbspro.2011.04.252

6. Kushner, E. (2003). English as global language: problems, dangers, opportunities. Diogenes, 50(2), 17-23. https://doi.org/10.1177/0392192103050002002

7. Anas, I., \& Musdariah, A. (2018). Being an E-Teacher: Preparing the ESL Teacher to Teach English with Technology. Journal of English Language Teaching and Linguistics, 3(1), 41-56. http://dx.doi.org/10.21462/jeltl.v3i1.102

8. Zhou, Z. (2018). Second Language Learning in the Technology-mediated Environments. Asian Education Studies, 3(1), 18. https://doi.org/10.20849/aes.v3i1.307

9. Schwartz, M., \& Yagmur, K. (2018). Early language development and education: teachers, parents and children as agents. Language, Culture and Curriculum, 31(3), 215-219.

10. Chang, S. Y. (2019). Beyond the English Box: Constructing and Communicating Knowledge Through Translingual Practices in the Higher Education Classroom. English Teaching \& Learning, 1-18. https://doi.org/10.1007/s42321-018-0014-4

11. Johnson, D. C., \& Stephens, C. (2018). Language Policy and Planning. In The Palgrave Handbook of Applied Linguistics Research Methodology, Palgrave Macmillan, London, 811-827.

12. Colpaert, J. (2018). Exploration of affordances of open data for language learning and teaching. Journal of technology and Chinese language teaching, 9(1), 1-14.

13. Kum, H. A. (2018). Language-Culture: Marginalisation or Opportunity in Cameroon's official 'state bilingualism'. Language, Identity and Symbolic Culture, 105.

14. Jung, Y., \& Lee, J. (2018). Learning engagement and persistence in massive open online courses (MOOCS). Computers \& Education. https://doi.org/10.1016/j.compedu.2018.02.013.

\section{Список литературь:}

1. Berge Z. L. The role of the online instructor/facilitator. http://www. emoderators.com/moderators/teach_online.html. 2009.

2. Grabe and Grabe. Integrating technology for meaningful learning. Houghton Mifflin, 2014.

3. Holec H. Autonomy in foreign language learning. Oxford: Oxford University Press, 2015.

4. Миргиязова М. М. Innovative technologies in teaching English // Молодой ученый. 2017. №25. C. 301-302.

5. Ghasemi B., Hashemi M. ICT: Newwave in English language learning/teaching // Procedia-

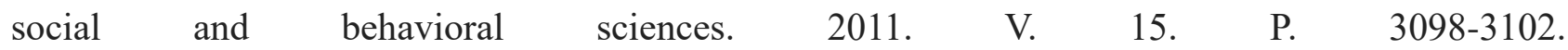
https://doi.org/10.1016/j.sbspro.2011.04.252.

6. Kushner E. English as global language: problems, dangers, opportunities // Diogenes. 2003. V. 50. №2. P. 17-23. https://doi.org/10.1177/0392192103050002002.

7. Anas I., Musdariah A. Being an E-Teacher: Preparing the ESL Teacher to Teach English with Technology // Journal of English Language Teaching and Linguistics. 2018. V. 3. №1. P. 41-56. http://dx.doi.org/10.21462/jelt1.v3i1.102.

8. Zhou Z. Second Language Learning in the Technology-mediated Environments // Asian Education Studies. 2018. V. 3. №1. P. 18. https://doi.org/10.20849/aes.v3i1.307.

9. Schwartz M., Yagmur K. Early language development and education: teachers, parents and children as agents //Language, Culture and Curriculum. 2018. V. 31. №3. P. 215-219. 
10. Chang S. Y. Beyond the English Box: Constructing and Communicating Knowledge Through Translingual Practices in the Higher Education Classroom // English Teaching \& Learning. 2019. P. 1-18. https://doi.org/10.1007/s42321-018-0014-4.

11. Johnson D. C., Stephens C. Language Policy and Planning // The Palgrave Handbook of Applied Linguistics Research Methodology. Palgrave Macmillan, London, 2018. P. 811-827.

12. Colpaert J. Exploration of affordances of open data for language learning and teaching // Journal of technology and Chinese language teaching. 2018. V. 9. №1. P. 1-14. http://www.tclt.us/journal/2018v9n1/colpaert.pdf.

13. Kum H. A. Language-Culture: Marginalisation or Opportunity in Cameroon's official 'state bilingualism' // Language, Identity and Symbolic Culture. 2018. P. 105.

14. Jung, Y., \& Lee, J. Learning engagement and persistence in massive open online courses (MOOCS) // Computers \& Education. 2018. https://doi.org/10.1016/j.compedu.2018.02.013.

Работа поступила

в редакиию 09.03.2019 г.
Принята к публикащии 14.03.2019 2.

Cite as $(A P A)$ :

Ergashev, K. (2019). Newwave in English Language Teaching. Bulletin of Science and Practice, 5(4), 426-430. https://doi.org/10.33619/2414-2948/41/61.

Ссылка для цчитирования:

Ergashev K. Newwave in English Language Teaching // Бюллетень науки и практики. 2019. T. 5. №4. C. 426-430. https://doi.org/10.33619/2414-2948/41/61. 